\title{
Escape performance of temperate king scallop, Pecten maximus under ocean warming and acidification
}

\author{
Burgel Schalkhausser · Christian Bock • \\ Hans-O. Pörtner · Gisela Lannig
}

Received: 24 April 2014 / Accepted: 18 September 2014 / Published online: 21 October 2014

(C) Springer-Verlag Berlin Heidelberg 2014

\begin{abstract}
Among bivalves, scallops are exceptional due to their capacity to escape from predators by swimming which is provided by rapid and strong claps that are produced by the phasic muscle interspersed with tonic muscle contractions. Based on the concept of oxygen and capacity-limited thermal tolerance, the following hypothesis was tested: ocean warming and acidification (OWA) would induce disturbances in aerobic metabolic scope and extracellular acid-case status and impair swimming performance in temperate scallops. Following longterm incubation under near-future OWA scenarios [20 vs. $10{ }^{\circ} \mathrm{C}$ (control) and $0.112 \mathrm{kPa} \mathrm{CO}$ (hypercapnia) vs. $0.040 \mathrm{kPa} \mathrm{CO}$ (normocapnic control)], the clapping performance and metabolic rates (MR) were measured in resting (RMR) and fatigued (maximum MR) king scallops, Pecten maximus, from Roscoff, France. Exposure to $\mathrm{OA}$, either alone or combined with warming, left MR and swimming parameters such as the total number of claps and clapping forces virtually unchanged. Only the duration of the escape response was affected by OA which caused earlier exhaustion in hyper- than in normocapnic scallops at $10{ }^{\circ} \mathrm{C}$. While maximum MR was unaffected, warm exposure increased RMR in both normocapnic and hypercapnic $P$. maximus resulting in similar $Q_{10}$ values of $\sim 2.2$. The increased costs of maintenance and the observation of strongly reduced haemolymph $\mathrm{PO}_{2}$ levels indicate that at $20{ }^{\circ} \mathrm{C}$ scallops have reached the upper thermal pejus
\end{abstract}

Communicated by J. P. Grassle.

B. Schalkhausser $(\bowtie) \cdot$ C. Bock $\cdot$ H.-O. Pörtner $\cdot$ G. Lannig Integrative Ökophysiologie, Alfred-Wegener-Institut HelmholtzZentrum für Polar- und Meeresforschung, Am Handelshafen 12, 27570, Bremerhaven, Germany

e-mail: Burgel.Schalkhausser@awi.de range with unbalanced capacities for aerobic energy metabolism. As a consequence, warming to $20{ }^{\circ} \mathrm{C}$ decreased mean phasic force during escape performance until fatigue. The observed prolonged recovery time in warm incubated scallops might be a consequence of elevated metabolic costs at reduced oxygen availability in the warmth.

\section{Introduction}

Scallops are exceptional among bivalves-when disturbed, they swim by ejecting water around the hinge. This escape response is achieved by powerful and fast shell adductions. The responsible adductor muscle consists of two functional types: the dominant phasic muscle (fast muscle) contracts rapidly and generates claps that enable scallops to swim by jet propulsion; the tonic muscle (catch muscle) contracts more slowly and operates at low energy costs; and it keeps the valves either closed for longer periods or at constant gaping for ventilation and feeding (Chantler 2006). The use of phasic and tonic contractions differs among species suggesting that lifestyle and shell morphology define muscle use during escape responses (Minchin 2003; Alejandrino et al. 2011; Tremblay et al. 2012; see also Guderley and Tremblay 2013). Furthermore, reliance on tonic contractions was higher in juvenile giant scallops, Placopecten magellanicus directly measured after handling stress compared with individuals given a 3-h recuperation period (Pérez et al. 2008a). Clapping via phasic contractions is fuelled by adenosine triphosphate (ATP), which is regenerated from phospho-L-arginine (PLA) followed by anaerobic and aerobic recovery after fatigue depending on closed/ open status of the scallop (Grieshaber 1978). The restoration of energy balance might be supported by tonic contractions that alternate with a series of phasic contractions 
allowing partial metabolic recovery of the adductor muscle (Pérez et al. 2008a, b).

In the light of the predominant use of anaerobic metabolism, the role of aerobic scope in exercise performance of scallops is thus not clear. Increasing costs for maintenance can reduce aerobic scope with trade-offs between energy-consuming processes relevant for performance/fitness such as growth, locomotion and reproduction (aerobic power budget concept by Guderley and Pörtner 2010; Guderley and Tremblay 2013). Environmental factors, in particular temperature, are known to affect the bioenergetics of marine ectotherms and thus performance and vulnerability (Pörtner et al. 2008; Guderley 2004; Somero 2011; Sokolova et al. 2012). Although physiological rates of ectotherms can acclimate/acclimatize to changing environmental conditions, aerobic metabolic rates in scallops and other bivalves remain tightly coupled to the surrounding temperature regime indicating only partial or no metabolic compensation (Aldridge et al. 1995; Pilditch and Grant 1999; Peck et al. 2002; Lannig et al. 2006). Also, thermal history more than actual habitat temperature might shape the thermal sensitivity of escape performance in scallops. Despite similar sampling temperature $\left(\sim 12{ }^{\circ} \mathrm{C}\right)$, performance of spring $P$. magellanicus was better at $6{ }^{\circ} \mathrm{C}$ than at $12{ }^{\circ} \mathrm{C}$ which contrasts to findings on $P$. magellanicus sampled in fall, which performed equally well at 6 and $12{ }^{\circ} \mathrm{C}$ (Guderley et al. 2009). However, irrespective of sampling time, an overall reduction in the effectiveness of escape response was observed at high temperatures $\left(18-19{ }^{\circ} \mathrm{C}\right)$. The mean phasic force of the giant scallop, $P$. magellanicus did not change, whereas the total number of claps, the mean duration and the rate of phasic contractions (claps $\min ^{-1}$ ) were lowered at high temperature (18-19 vs. $\left.6 / 12{ }^{\circ} \mathrm{C}\right)$, paralleled by an increased reliance on tonic contractions in the warmth (Guderley et al. 2009). Similarly, following cold exposure, only partial compensation of clapping performance was observed in P. magellanicus after approximately a week of cold acclimation. Recuperation from exhaustive exercise was significantly impaired in cold-exposed scallops compared to scallops under control conditions (8 vs. $18^{\circ} \mathrm{C}$, Lafrance et al. 2002).

The ongoing processes of ocean warming and acidification (OWA), as a consequence of anthropogenic $\mathrm{CO}_{2}$ emissions, affect marine biota (Melzner et al. 2009; Sokolova et al. 2012; Wittmann and Pörtner 2013; IPCC 2014). According to the concept of oxygen and capacity-limited thermal tolerance (OCLTT, Pörtner 2001, 2002), synergistic effects of elevated temperature and ocean acidification will narrow the functional scope of marine ectotherms resulting in impaired performance capacities (Pörtner and Farrell 2008). Furthermore, synergistic effects of warming and acidification were suggested to cause reduced calcification rates in the blue mussel, Mytilus galloprovincialis, in seasonal experiments along a natural $\mathrm{pH}$ gradient near volcanic $\mathrm{CO}_{2}$ vents off Ischia, Italy [pH 7.4 (May) vs. pH 8.1 (September), Rodolfo-Metalpa et al. 2011]. A combination of low pH and elevated temperatures increased lipofuscin accumulation (a marker for physiological stress) in the clam, Arctica islandica $\left(7.5\right.$ vs. $16^{\circ} \mathrm{C}, 0.039$ vs. $0.136 \mathrm{kPa} \mathrm{CO}_{2}$, Hiebenthal et al. 2013). Rosa and Seibel (2008) found reduced aerobic and locomotory scope for exercise in the jumbo squid, Dosidicus gigas under OWA conditions $\left(10\right.$ vs. $20{ }^{\circ} \mathrm{C} ; 0.039$ vs. $\sim 0.1 \mathrm{kPa} \mathrm{CO}_{2}$ ) with suggested implications for predator-prey interactions. Such a synergism of OA and temperature stress was also shown for the "cold side" of the scallop's thermal tolerance range. Previous work in our laboratory revealed high mortality among the boreal king scallop, Pecten maximus from Norway (sampled in February at $3-5{ }^{\circ} \mathrm{C}$ ), when exposed to a combination of high $\mathrm{CO}_{2}$ levels and low winter temperature $\left(0.11 \mathrm{kPa} \mathrm{CO}_{2}\right.$ at $4{ }^{\circ} \mathrm{C}$, Schalkhausser et al. 2013). Mortality was negligible during simultaneous exposure to elevated $\mathrm{CO}_{2}$ levels at higher temperature $(0.11 \mathrm{kPa}$ $\mathrm{PCO}_{2}$ at $10{ }^{\circ} \mathrm{C}$ ), but swimming performance was impaired in hyper- compared to normocapnic $P$. maximus.

King scallops, P. maximus are widely distributed, from northern Norway to West Africa (Minchin 2003) and economically important in fisheries and mariculture. They are predominantly found in the north-eastern Atlantic, and king scallops are currently the most important resource species in the Roscoff region of France where the organisms of our study have been obtained (IFREMER 2011).

The present study sets out to investigate locomotor and metabolic physiology of a temperate population of $P$. maximus to test the hypothesis of impaired performance due to lowered aerobic scope under OWA conditions according to the OCLTT concept. The International Panel for Climate Change (IPCC 2014) proposed an increase in global mean temperature by $3-5{ }^{\circ} \mathrm{C}$, and $\mathrm{PCO}_{2}$ might rise up to $\geq 1,000 \mathrm{ppm}(\approx 0.10 \mathrm{kPa})$ within the year 2100 depending on the scenario. Against the background that environmental temperature of $P$. maximus from Roscoff varies from 10 to $16{ }^{\circ} \mathrm{C}$, we assessed escape performance (rate and force of phasic and tonic contractions) and aerobic energy metabolism (routine and maximal metabolic rate, aerobic scope) in scallops exposed to control $\left(0.040 \mathrm{kPa} P \mathrm{PO}_{2}\right)$ and elevated $\left(0.112 \mathrm{kPa} \mathrm{PCO}_{2}\right) \mathrm{CO}_{2}$ levels at either control $\left(10^{\circ} \mathrm{C}\right)$ or elevated $\left(20^{\circ} \mathrm{C}, \sim 5^{\circ} \mathrm{C}\right.$ above the environmental summer mean) temperature.

\section{Materials and methods}

Scallop collection and holding conditions

Wild living $P$. maximus were collected at a depth of $\sim 20 \mathrm{~m}$ by SCUBA divers from Marine Station Roscoff ("Station 
Table 1 Parameters of sea water during long-term incubations of $P$. maximus during normocapnia and hypercapnia at different temperatures (10 and $20^{\circ} \mathrm{C}$ incubation)

\begin{tabular}{llcc}
\hline & Parameter & Normocapnia & Hypercapnia \\
\hline $10{ }^{\circ} \mathrm{C}$ & $\mathrm{PCO}_{2}(\mathrm{kPa})$ & $0.037 \pm 0.007$ & $0.106 \pm 0.023$ \\
& Temperature $\left({ }^{\circ} \mathrm{C}\right)$ & $9.70 \pm 0.43$ & $9.57 \pm 0.50$ \\
& $\mathrm{pH}(\mathrm{NBS}-$ scale) & $8.19 \pm 0.07$ & $7.80 \pm 0.10$ \\
& $\mathrm{pH}($ total scale) & $8.09 \pm 0.10$ & $7.70 \pm 0.09$ \\
& Salinity $\left(S_{\mathrm{P}}\right)$ & $32.29 \pm 0.53$ & $32.23 \pm 0.62$ \\
$20{ }^{\circ} \mathrm{C}$ & $2.25 \pm 0.04$ & $2.36 \pm 0.05$ \\
& DIC $(\mathrm{mM})$ & $0.045 \pm 0.004$ & $0.117 \pm 0.025$ \\
& $P C \mathrm{O}_{2}(\mathrm{kPa})$ & $19.49 \pm 0.31$ & $19.81 \pm 0.16$ \\
& Temperature $\left({ }^{\circ} \mathrm{C}\right)$ & $7.87 \pm 0.07$ \\
& $\mathrm{pH}(\mathrm{NBS}-\mathrm{scale})$ & $7.15 \pm 0.03$ & $7.66 \pm 0.08$ \\
& $\mathrm{pH}($ total scale $)$ & $33.35 \pm 0.44$ & $33.22 \pm 0.39$ \\
& Salinity $\left(S_{\mathrm{P}}\right)$ & $2.21 \pm 0.04$ & $2.29 \pm 0.03$ \\
\hline
\end{tabular}

Data are mean $\pm \mathrm{SD}$ with $N=57-62\left(10^{\circ} \mathrm{C}\right), N=17-22\left(20^{\circ} \mathrm{C}\right)$; values at $10{ }^{\circ} \mathrm{C}$ contain data of incubation from 2010 to 2011

NBS, National Bureau of Standards; $\mathrm{PCO}_{2}$, sea water partial pressure of $\mathrm{CO}_{2}$; DIC, dissolved inorganic carbon

Biologique de Roscoff", France) at Morlaix Bay (Baie de Morlaix, Les Grandes Fourches, France; 48 $42^{\prime} 33.6^{\prime \prime} \mathrm{N}$, $\left.3^{\circ} 55^{\prime} 59.30^{\prime \prime} \mathrm{W}\right)$. Environmental mean surface temperatures vary from 9.7 to $16.3{ }^{\circ} \mathrm{C}$ with $\mathrm{pH}_{\mathrm{NBS}}$ values of $8.04-8.21$ ( $\mathrm{pH}$ scale of the National Bureau of Standards) in this area (monthly means February 2000-October 2012; data provided by "Service d'Observation en Milieu Littoral, INSUCNRS, Estacade", http://somlit-db.epoc.u-bordeaux1.fr/ download.php?serie $=\mathrm{ST}$ ). Scallops were collected in two batches (first batch in July 2010, second batch in September 2011) at similar environmental temperatures around 10-12 ${ }^{\circ} \mathrm{C}$ (2010) and $11-14{ }^{\circ} \mathrm{C}$ (2011). Scallops were transported to the Alfred Wegener Institute (Bremerhaven, Germany) and placed in recirculating aerated aquarium systems $\left(\sim 10{ }^{\circ} \mathrm{C}\right.$ and salinity of $\left.32 S_{\mathrm{p}}\right)$. After 2 weeks of recovery, the shells were carefully scrubbed to remove epibionts. Randomized groups of labelled scallops were incubated in temperature-controlled rooms in recirculation systems (one system per group, comprising header, receiver and reservoir tanks and two incubation tanks (each with $\leq 10$ scallops) similar to the systems described by Michaelidis et al. 2005 or Findlay et al. 2010). Due to logistic constraints, scallops sampled in 2010 were incubated at $10{ }^{\circ} \mathrm{C}$ only, while scallops from 2011 were incubated at 10 and $20{ }^{\circ} \mathrm{C}$. The systems were continuously bubbled with a specific gas mixture to reach sea water $P \mathrm{CO}_{2}$ values of either $\sim 0.039 \mathrm{kPa}$ (390 $\mu \mathrm{atm}$, normocapnia) or $\sim 0.112 \mathrm{kPa}$ $(1,120 \mu$ atm, $0.3-0.4$ units below present global average $\mathrm{pH}$, projected for 2100, hypercapnia; see Schalkhausser et al. 2013). The OA incubation lasted at least $50 \mathrm{~d}$. Scallops were drip-fed live phytoplankton three times per week [DT's Premium Reef Blend (Nannochloropsis osculata, Phaeodactylum sp., Chlorella sp.; $25.3 \mu \mathrm{g} \mathrm{L}^{-1}$ phytoplankton dry weight)] for a minimum of $6 \mathrm{~h} \mathrm{~d}^{-1}$ at a concentration of at least $7.62 \times 10^{5}$ cells $\mathrm{g}^{-1}$ bivalve biomass $\mathrm{h}^{-1}\left(10^{\circ} \mathrm{C}\right)$ or $1.07 \times 10^{6}$ cells $\mathrm{g}^{-1}$ bivalve biomass $\mathrm{h}^{-1}$ $\left(20{ }^{\circ} \mathrm{C}\right.$ ), respectively (water circulation was stopped during feeding). Water was exchanged at least twice a week, and tanks were cleaned of faeces and remaining food items every day. Water parameters (Table 1) were measured twice a week as described by Schalkhausser et al. (2013). Shell dimensions of the scallops did not differ among groups (both years) prior to and after incubation resulting in overall mean $\pm \mathrm{SD}$ of $119.6 \pm 6.8 \mathrm{~mm}$ (height; $N=71$ ), $105.7 \pm 5.8 \mathrm{~mm}$ (length; $N=71$ ) and $31.1 \pm 2.0 \mathrm{~mm}$ (width; $N=71$ ). Also tissue dry weight (DW) which was determined after drying at $75{ }^{\circ} \mathrm{C}$ for 10-16 h, when no detectable mass changes were observed, was similar among groups with an overall mean \pm SD of $13.99 \pm 2.67 \mathrm{~g}(N=67)$. All measurements were carried out in Oct/Nov 2010 and Oct/Nov 2011. Condition index (CI) and the muscle index (MI) were calculated after Shriver et al. (2002) and Pazos et al. (1997) by dividing the tissue DW (total and muscle DW, respectively) with shell DW multiplied by 100 .

\section{Determination of clapping performance}

Measurements of clapping performance were achieved using the same equipment and methods as described in detail in our previous study (Schalkhausser et al. 2013). In brief, after recovery from handling stress clapping was induced by injection of distilled water via a thin, gas-tight tube into the mantle cavity. Such injections, or touching the mantle with an arm of their starfish predator, stimulates scallops to exercise until they become exhausted and unresponsive to further stimulation (Bailey et al. 2003; Guderley et al. 2008). The number of claps and force strengths of adductor muscle contractions were determined until the scallop was exhausted (no response to further stimulation). Total force $F_{\text {total }}$ (total force produced by one scallop during escape until fatigue), mean phasic force $F_{\text {mean phasic }}$ (mean force $\mathrm{clap}^{-1}$ ) and tonic force $F_{\text {tonic }}$ (force produced by one scallop during tonic phases [= not clapping]) were determined using the following formula (see Schalkhausser et al. 2013). $F_{\text {total }}(\mathrm{N})$ was calculated by dividing the force impulse [measured force $(\mathrm{N})$ multiplied by measured time (s)] by the total time, $F_{\text {total }}=\frac{\int f \mathrm{~d} t}{t_{\text {total }}}, F_{\text {mean phasic }}(\mathrm{N})$ was calculated by dividing the sum of all clap forces $\left(F_{\text {clap }}\right)$ by the number of claps $(n), F_{\text {mean phasic }}=\frac{\sum_{i}^{n} F_{\text {clap }}}{n}=\frac{F_{\text {phasic }}}{n}$, and $F_{\text {tonic }}(\mathrm{N})$ by subtracting $F_{\text {phasic }}$ from $F_{\text {total }}$, $F_{\text {tonic }}=F_{\text {total }}-F_{\text {phasic }}$. 
Determination of respiration

Measurements of routine and maximal metabolic rate after fatigue (RMR; MMR) were conducted following our previous protocol (see Schalkhausser et al. 2013). In brief, after recovery from handling stress, oxygen consumption, $\dot{M}_{\mathrm{O} 2}$ $\left[\mu \mathrm{mol} \mathrm{O} \mathrm{h}^{-1}(\mathrm{~g} \mathrm{DW})^{-1}\right](\mathrm{g} \mathrm{DW}=$ gram dry weight $)$ was determined on non-fed scallops during rest (RMR) and after exhaustive exercise (MMR) using intermittent flow respirometry with three to five trials individual ${ }^{-1}$. Intervals were chosen, so oxygen partial pressures were never $<15 \mathrm{kPa}$ in the chamber. Factorial aerobic scope (FAS) was calculated as the ratio of maximum to resting rate (MMR/ RMR, Cutts et al. 2002) and net aerobic scope (NAS) as the difference between MMR and RMR (Fry 1947). Both FAS and NAS are often reported, and we follow Clark et al. (2013) in showing both calculations.

Recovery periods following exhaustive exercise were determined from respiration measurements and defined as the time the scallop required to return from MMR to initial RMR. The $Q_{10\left(10-20{ }^{\circ} \mathrm{C}\right)}$ values were calculated after Precht et al. (1973).

\section{Determination of haemolymph gas parameters}

Haemolymph was sampled from the adductor muscle using a Hamilton syringe. Haemolymph $P_{\mathrm{e}} \mathrm{CO}_{2}, P_{\mathrm{e}} \mathrm{O}_{2}$ and $\mathrm{pH}_{\mathrm{e}}$ were analysed using a blood gas analyser (MT 33, Eschweiler, Germany); total $\mathrm{CO}_{2}\left(\mathrm{C}_{\mathrm{e}} \mathrm{CO}_{2}\right)$ was analysed by a gas chromatograph (Agilent 6890 N GC System, Agilent Technologies, USA); the concentration of apparent bicarbonate $\left[\mathrm{HCO}_{3}^{-}\right]_{\mathrm{e}}$ was calculated using the following values of the solubility of $\mathrm{CO}_{2}$ in sea water $\left(\alpha \mathrm{CO}_{2}\right)$ : $\alpha \mathrm{CO}_{2}=0.465 \mathrm{mmol} \mathrm{L}{ }^{-1} \mathrm{kPa}^{-1}$ at $10{ }^{\circ} \mathrm{C}$ and salinity of $32.8 S_{\mathrm{P}}, \alpha \mathrm{CO}_{2}=0.343 \mathrm{mmol} \mathrm{L}{ }^{-1} \mathrm{kPa}^{-1}$ at $20{ }^{\circ} \mathrm{C}$ and salinity of $33.3 S_{\mathrm{P}}$ (calculated from Weiss 1974; see Schalkhausser et al. 2013). In 2010, methodological problems hampered the proper and accurate determination of $P_{\mathrm{e}} \mathrm{CO}_{2}$ during sampling of the hypercapnic group and reliable $P_{\mathrm{e}} \mathrm{CO}_{2}$ values could only be determined in two scallops.

\section{Statistics}

Data sets were analysed using SigmaPlot (Version 12.0, Systat Software, Inc.), GraphPad Prism (Version 4.0a, GraphPad Software Inc.) and R [2.15.1 GUI 1.52 Leopard build 32-bit (6188)]. A linear mixed-effects model fit by REML (package nlme) combined with an ANOVA to create a three-way repeated-measurements ANOVA was used to determine synergistic effects of $\mathrm{CO}_{2}$ exposure, temperature and exercise level on respiration measurements $(P$ value $<0.05)$. Interactions between effects of $\mathrm{CO}_{2}$ exposure and year or temperature on haemolymph parameters, force
Table 2 Morphological indices of $P$. maximus from two different sampling years following long-term incubation under normocapnia (sea water $\mathrm{PCO}_{2} \sim 0.040 \mathrm{kPa}$ ) and hypercapnia (sea water $\left.\mathrm{PCO}_{2} \sim 0.112 \mathrm{kPa}\right)$ at two different temperatures $\left(10,20^{\circ} \mathrm{C}\right)$

\begin{tabular}{llcc}
\hline Year/temperature & Parameter & Normocapnia & Hypercapnia \\
\hline $2010 / 10{ }^{\circ} \mathrm{C}$ & Condition index & $11.9 \pm 1.3(17)$ & $12.0 \pm 1.2(12)$ \\
& Muscle index & $2.8 \pm 0.5(16)^{\mathrm{a}}$ & $2.8 \pm 0.6(13)^{\mathrm{a}}$ \\
$2011 / 10{ }^{\circ} \mathrm{C}$ & Condition index & $13.6 \pm 2.3(9)$ & $13.4 \pm 1.5(6)$ \\
& Muscle index & $4.3 \pm 0.4(9)$ & $4.3 \pm 0.4(5)$ \\
$2011 / 20{ }^{\circ} \mathrm{C}$ & Condition index & $13.0 \pm 1.0(9)$ & $11.7 \pm 1.5(9)$ \\
& Muscle index & $3.8 \pm 0.7(10)^{\#}$ & $3.3 \pm 0.2(8)^{\#}$ \\
\hline
\end{tabular}

Data are mean \pm SD with $(N)$

\# Significant differences between 10 and $20{ }^{\circ} \mathrm{C}$ data at same $\mathrm{CO}_{2}$ level

a Significant difference between sampling years at same $\mathrm{CO}_{2}$ level

measurements, metabolic rates, net and FAS were considered significant if the probability of type II error was $<0.05$ using two-way analysis of variance in combination with a Holm-Sidak test. One-way ANOVA in combination with a Bonferroni's multiple comparison test was $<0.05$ to identify differences in morphological parameters [shell dimensions, tissue mass, condition and muscle indices (MI)]. Results are presented in box plots, and values are given as mean \pm SD unless otherwise stated.

\section{Results}

Mortality, condition and muscle indices

Neither warming nor OA exposure nor the combination of the two affected the well-being of temperate $P$. maximus as indicated by low mortality rates of $9 \%$ (normocapnia) and $0 \%$ (hypercapnia) at $10{ }^{\circ} \mathrm{C}$ (combined for both sampling years) and of $20 \%$ (normocapnia) and $9 \%$ (hypercapnia) at $20^{\circ} \mathrm{C}$. Condition indices were similar among all groups, whereas MI was significantly affected by year of sampling (Table 2; ANOVA, $F(1,41)=89.459 P<0.001$ ). Furthermore, warming from 10 to $20{ }^{\circ} \mathrm{C}$ significantly reduced MI (ANOVA, $F(1,30)=17.205 P<0.001$ ), with a further reduction following additional $\mathrm{OA}$ exposure at $20{ }^{\circ} \mathrm{C}$ (Holm-Sidak, $t(1,17)=2.386 P=0.024$; Table 2).

Haemolymph acid-base parameters

The data for all groups are shown in Table 3. Sampling year affected haemolymph parameters in resting scallops yielding significantly lower $\mathrm{C}_{\mathrm{e}} \mathrm{CO}_{2}$ and $\left[\mathrm{HCO}_{3}{ }^{-}\right]_{\mathrm{e}}$ values in scallops sampled in 2010 than in 2011, irrespective of $\mathrm{CO}_{2}$ levels $\left(\mathrm{C}_{\mathrm{e}} \mathrm{CO}_{2}\right.$ : ANOVA, $F(1,40)=15.494$ $P<0.001 ;\left[\mathrm{HCO}_{3}^{-}\right]_{\mathrm{e}}:$ ANOVA, $F(1,40)=14.549$ 
Table 3 Haemolymph blood gas parameters of $P$. maximus at rest from two different sampling years following long-term incubation under normocapnia (sea water $\mathrm{PCO}_{2} \sim 0.040 \mathrm{kPa}$ ) and hypercapnia (sea water $\mathrm{PCO}_{2} \sim 0.112 \mathrm{kPa}$ ) at two different temperatures (10, $\left.20{ }^{\circ} \mathrm{C}\right)$

\begin{tabular}{|c|c|c|c|}
\hline $\begin{array}{l}\text { Year/tempera- } \\
\text { ture }\end{array}$ & Parameter & Normocapnia & Hypercapnia \\
\hline \multirow[t]{6}{*}{$2010 / 10^{\circ} \mathrm{C}$} & $P_{\mathrm{e}} \mathrm{O}_{2}(\mathrm{kPa})$ & $10.86 \pm 2.67$ & $13.37 \pm 3.99$ \\
\hline & $P_{\mathrm{e}} \mathrm{CO}_{2}(\mathrm{kPa})$ & $0.14 \pm 0.03$ & $0.26 / 0.21(N=2)$ \\
\hline & $\begin{array}{l}\mathrm{pH}_{\mathrm{e}}(\mathrm{NBS}- \\
\text { scale) }\end{array}$ & $7.51 \pm 0.07$ & $7.34 \pm 0.10^{*}$ \\
\hline & $\mathrm{C}_{\mathrm{e}} \mathrm{CO}_{2}(\mathrm{mM})$ & $1.92 \pm 0.18^{\mathrm{a}}$ & $2.22 \pm 0.18^{\mathrm{a}, *}$ \\
\hline & $\begin{array}{l}{\left[\mathrm{HCO}_{3}^{-}\right]_{\mathrm{e}}} \\
(\mathrm{mM})\end{array}$ & $1.85 \pm 0.18^{\mathrm{a}}$ & $2.14 \pm 0.19^{\mathrm{a}, *}$ \\
\hline & $N$ & $14-16$ & $11-13$ \\
\hline \multirow[t]{6}{*}{$2011 / 10^{\circ} \mathrm{C}$} & $P_{\mathrm{e}} \mathrm{O}_{2}(\mathrm{kPa})$ & $9.73 \pm 3.69$ & $13.34 \pm 3.17^{*}$ \\
\hline & $P_{\mathrm{e}} \mathrm{CO}_{2}(\mathrm{kPa})$ & $0.13 \pm 0.04$ & $0.21 \pm 0.03 *$ \\
\hline & $\begin{array}{l}\mathrm{pH}_{\mathrm{e}}(\mathrm{NBS}- \\
\text { scale) }\end{array}$ & $7.52 \pm 0.09$ & $7.31 \pm 0.06^{*}$ \\
\hline & $\mathrm{C}_{\mathrm{e}} \mathrm{CO}_{2}(\mathrm{mM})$ & $2.17 \pm 0.34$ & $2.52 \pm 0.07 *$ \\
\hline & $\begin{array}{c}{\left[\mathrm{HCO}_{3}^{-}\right]_{\mathrm{e}}} \\
(\mathrm{mM})\end{array}$ & $2.10 \pm 0.32$ & $2.41 \pm 0.06^{*}$ \\
\hline & $N$ & $8-9$ & $5-6$ \\
\hline \multirow[t]{6}{*}{$2011 / 20^{\circ} \mathrm{C}$} & $P_{\mathrm{e}} \mathrm{O}_{2}(\mathrm{kPa})$ & $6.24 \pm 1.72^{\#}$ & $6.14 \pm 1.52^{\#}$ \\
\hline & $P_{\mathrm{e}} \mathrm{CO}_{2}(\mathrm{kPa})$ & $0.16 \pm 0.03$ & $0.23 \pm 0.06^{*}$ \\
\hline & $\begin{array}{l}\mathrm{pH}_{\mathrm{e}}(\mathrm{NBS}- \\
\text { scale) }\end{array}$ & $7.49 \pm 0.08$ & $7.34 \pm 0.12^{*}$ \\
\hline & $\mathrm{C}_{\mathrm{e}} \mathrm{CO}_{2}(\mathrm{mM})$ & $1.82 \pm 0.23^{\#}$ & $2.16 \pm 0.14^{\#, *}$ \\
\hline & $\begin{array}{c}{\left[\mathrm{HCO}_{3}^{-}\right]_{\mathrm{e}}} \\
(\mathrm{mM})\end{array}$ & $1.76 \pm 0.23^{\#}$ & $2.08 \pm 0.14^{\#, *}$ \\
\hline & $N$ & $8-10$ & $9-10$ \\
\hline
\end{tabular}

Data are mean \pm SD with $N$ given for the different groups; expect for $P_{\mathrm{e}} \mathrm{CO}_{2}$ under hypercapnia in 2010 where single values are given with $N$ in parentheses

$P_{\mathrm{e}} \mathrm{O}_{2}$ and $P_{\mathrm{e}} \mathrm{CO}_{2}$, extracellular partial pressure of $\mathrm{O}_{2}$ and $\mathrm{CO}_{2}$, respectively; $\mathrm{pH}_{\mathrm{e}}$, extracellular $\mathrm{pH}$; NBS, National Bureau of Standards; $\mathrm{C}_{\mathrm{e}} \mathrm{CO}_{2}$ extracellular total dissolved inorganic carbon; $\left[\mathrm{HCO}_{3}{ }^{-}\right]_{\mathrm{e}}$, extracellular bicarbonate concentration

* Significant differences between normocapnic and hypercapnic data at same temperature

\# Significant differences between 10 and $20{ }^{\circ} \mathrm{C}$ data at same $\mathrm{CO}_{2}$ level

${ }^{\text {a }}$ Significant difference between sampling years at same $\mathrm{CO}_{2}$ levels

$P<0.001$ ). Warming significantly reduced $P_{\mathrm{e}} \mathrm{O}_{2}$ by nearly $50 \%$ as well as $\mathrm{C}_{\mathrm{e}} \mathrm{CO}_{2}$ and $\left[\mathrm{HCO}_{3}{ }^{-}\right]_{\mathrm{e}}$ values in both, normocapnia- and hypercapnia-exposed scallops $\left(P_{\mathrm{e}} \mathrm{O}_{2}\right.$ : ANOVA, $F(1,32)=34.070 P<0.001 ; \mathrm{C}_{\mathrm{e}} \mathrm{CO}_{2}$ : ANOVA, $F(1,31)=19.347 P<0.001 ;\left[\mathrm{HCO}_{3}{ }^{-}\right]_{\mathrm{e}}:$ ANOVA, $F(1$, $31)=18.221 P<0.001)$. Following OA exposure in both years or temperatures, scallops displayed significantly elevated $P_{\mathrm{e}} \mathrm{CO}_{2}, \mathrm{C}_{\mathrm{e}} \mathrm{CO}_{2}$ and $\left[\mathrm{HCO}_{3}^{-}\right]_{\mathrm{e}}$ and significantly lowered $\mathrm{pH}_{\mathrm{e}}$ (different years $P_{\mathrm{e}} \mathrm{CO}_{2}$ : ANOVA, $F(1,26)=18.059 P<0.001-$ no interaction calculable;
$\mathrm{C}_{\mathrm{e}} \mathrm{CO}_{2}$ : ANOVA, $F(1,31)=19.347 P<0.001 ;\left[\mathrm{HCO}_{3}{ }^{-}\right]_{\mathrm{e}}$ : ANOVA, $F(1,40)=18.796 P<0.001 ; \mathrm{pH}_{\mathrm{e}}$ : ANOVA, $F(1$, 38) $=43.067 P<0.001$; different temperatures $P_{\mathrm{e}} \mathrm{CO}_{2}$ : ANOVA, $F(1,30)=20.225 P<0.001 ; \mathrm{C}_{\mathrm{e}} \mathrm{CO}_{2}$ : ANOVA, $F(1,31)=17.606 P<0.001 ;\left[\mathrm{HCO}_{3}{ }^{-}\right]_{\mathrm{e}}$ : ANOVA, $F(1$, $31)=16.208 P<0.001 ; \mathrm{pH}_{\mathrm{e}}$ : ANOVA, $F(1,29)=24.940$ $P<0.001)$. The hypercapnia-induced changes were similar, irrespective of incubation temperature indicating that warming and acidification had no synergistic effects.

\section{Clapping performance and metabolic rate}

The clapping performance of $P$. maximus under the various conditions was similar between sampling years in both normocapnia- and hypercapnia-exposed scallops at $10{ }^{\circ} \mathrm{C}$ (Fig. 1). The number of claps was neither affected by warming nor by OA exposure nor by the combination of both resulting in an overall mean of $69 \pm 20$ claps until fatigue of scallops sampled in 2011 (Fig. 1a). Warming modified clapping forces, whereas OA, solely or in combination with warming, had no effect. Exposure to $20{ }^{\circ} \mathrm{C}$ significantly increased total force $F_{\text {total }}$ and tonic force $F_{\text {tonic }}$ by $\sim 80 \%$ in the normocapnic group $\left(F_{\text {total }}\right.$ : Holm-Sidak, $t(1,18)=2.315$ $P=0.028 ; F_{\text {tonic }}:$ Holm-Sidak, $\left.t(1,18)=2.331 P=0.027\right)$, and, insignificantly by $\sim 30 \%$ in the hypercapnic group likely due to the observed high variation in this group at $10{ }^{\circ} \mathrm{C}$ (Fig. 1b, d). The normocapnic and hypercapnic groups at $20^{\circ} \mathrm{C}$ both showed significantly decreased mean phasic force $F_{\text {mean phasic }}$ (normocapnia $24 \%$, hypercapnia $31 \%$ ) compared to the respective values at $10{ }^{\circ} \mathrm{C}$ (normocapnia: Holm-Sidak, $t(1,17)=2.077 P=0.047$; hypercapnia: Holm-Sidak, $t(1,13)=2.522 P=0.018$; Fig. 1c).

No clear pattern was observed for the duration of the escape response (Fig. 2a). Irrespective of $\mathrm{CO}_{2}$ level, time to fatigue of $10^{\circ} \mathrm{C}$ incubated P. maximus was similar between sampling years. However, in 2011, but not in 2010, scallops displayed a longer-lasting escape response in the normocapnic than in the hypercapnic group $\left(201110{ }^{\circ} \mathrm{C}\right.$ : Holm-Sidak, $t(1,14)=2.078 P=0.046)$. Warming significantly reduced the duration of the escape response in normocapnia- but not in hypercapnia-exposed $P$. maximus linked to the significant interaction between temperature and OA (ANOVA, $F(1,32)=5.549 P=0.025$ ). Sampling year and warming, but not $\mathrm{OA}$ exposure, affected the time to recover from exhaustive exercise (Fig. 2b). Irrespective of OA exposure, it was significantly less by $2 \mathrm{~h}$ in $P$. maximus in 2010 than in 2011 (ANOVA, $F(1,19)=17.776$ $P<0.001$ ) and significantly extended by warming (lasting $\sim 9 \mathrm{~h}$ at $20{ }^{\circ} \mathrm{C}$ compared to $6-7 \mathrm{~h}$ at $10{ }^{\circ} \mathrm{C}$; ANOVA, $F(1$, 22) $=21.567 P<0.001)$.

Sampling year altered resting but not maximal metabolic rate of $P$. maximus resulting in marginally but significantly lowered resting metabolism in 2010 than in 2011 (ANOVA, 

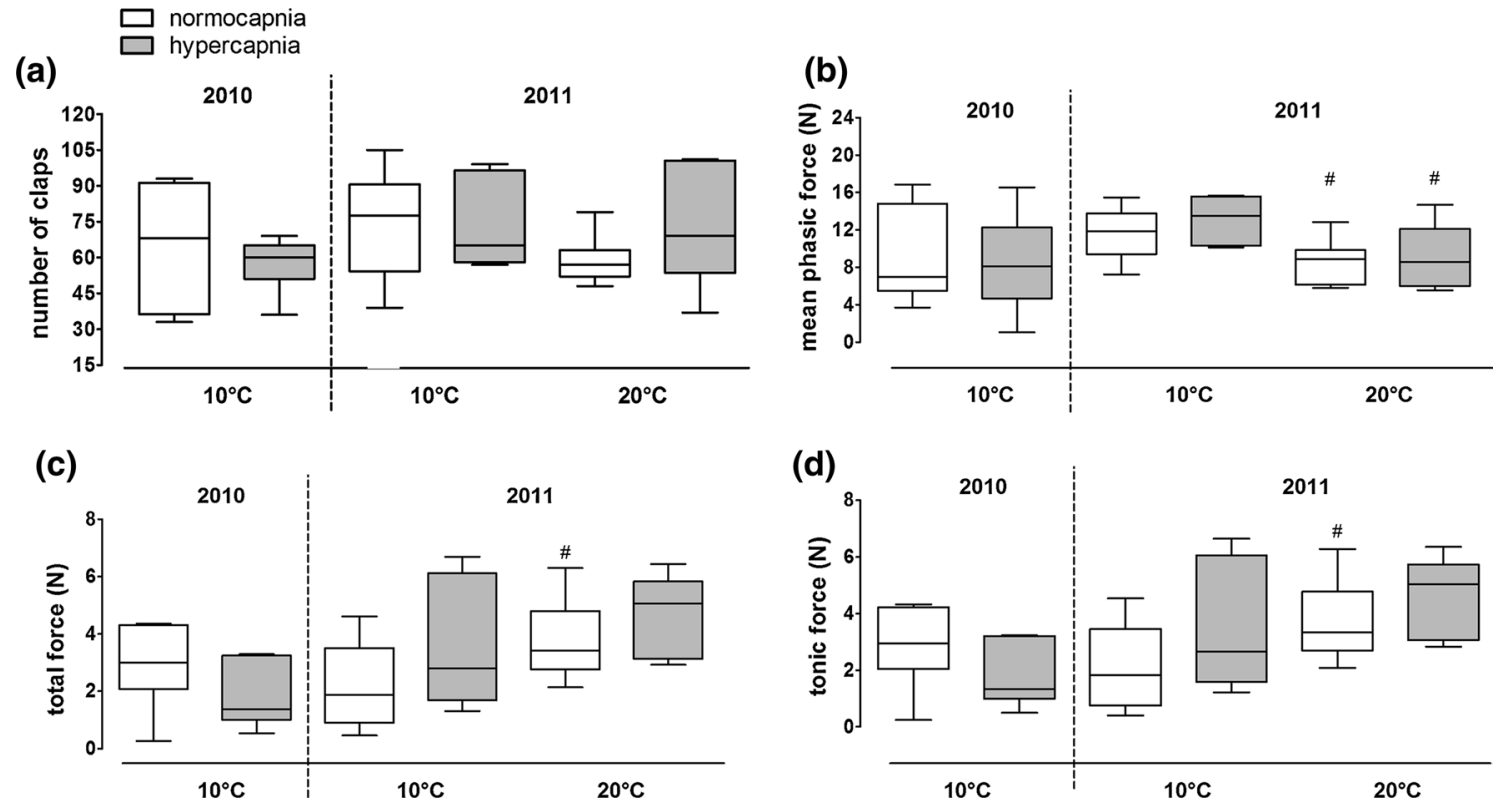

Fig. 1 Clapping performance of $P$. maximus from two different sampling years following long-term incubation under normocapnia (sea water $\mathrm{PCO}_{2} \sim 0.040 \mathrm{kPa}$ ) and hypercapnia (sea water $\left.\mathrm{PCO}_{2} \sim 0.112 \mathrm{kPa}\right)$ at two different temperatures $\left(10,20{ }^{\circ} \mathrm{C}\right)$. a Total number of claps until fatigue. b Total force. c Mean phasic force. d

$F(1,25)=12.427 P=0.002)$ without any significant effect on aerobic scopes (Fig. 3). Warming from 10 to $20{ }^{\circ} \mathrm{C}$ significantly increased resting metabolic rate (RMR) in both normocapnia- and hypercapnia-exposed groups (normocapnia: Holm-Sidak, $t(1,11)=6.425 P<0.001$; hypercapnia: Holm-Sidak, $t(1,13)=7.089 P<0.001)$, resulting in similar $Q_{10}$ values of 2.3 (normocapnia) and 2.2 (hypercapnia), respectively (Fig. 3a). Maximum metabolic rate (MMR) was less responsive to warming $\left[Q_{10}\right.$ values of 1.2 (normocapnia) and 1.5 (hypercapnia), respectively] (Fig. 3a). The rise in metabolic rate from RMR to MMR was 2.3 at $10{ }^{\circ} \mathrm{C}$ compared to 2.1 at $20{ }^{\circ} \mathrm{C}$ resulting in a significantly reduced FAS in the warmth (ANOVA, $F(1$, $24)=31.922 P<0.001$; Fig. 3b). Warming left NAS, an indication of the absolute change in respiration rates, more or less unchanged, explicable by the quite high variation in MMR data. Irrespective of sampling year or incubation temperature, additional OA exposure had no effect on resting and on maximum metabolic rate and there was no synergistic impact of OWA on metabolic rates of $P$. maximus. Furthermore, there was no synergistic impact of OA exposure, temperature and exercise level on metabolic rates.

\section{Discussion}

Although some parameters (MI, haemolymph bicarbonate concentration and RMR) differed in temperate $P$. maximus

Tonic force. 2010: $N=7-8 ; 2011: N=8-10$ (normocapnia, $10{ }^{\circ} \mathrm{C}$ ), $N=5$ (hypercapnia, $10{ }^{\circ} \mathrm{C}$ ), $N=9-11$ (normocapnia, $20^{\circ} \mathrm{C}$ ), $N=7-9$ (hypercapnia, $2{ }^{\circ} \mathrm{C}$ ). Data are depicted in boxplots. ${ }^{\#} \mathrm{Sig}-$ nificant differences between 10 and $20^{\circ} \mathrm{C}$ data at same $\mathrm{CO}_{2}$ level

when sampled in two consecutive years (2010 vs. 2011), the observed differences did not affect metabolic scopes or clapping performance. Only the time to recover from exhaustive exercise was reduced in $P$. maximus sampled in 2010, a potential result of seasonal variations in the thermal history (see "Introduction" and Guderley et al. 2009). Irrespective of sampling year, temperate $P$. maximus were insensitive to our chosen ocean acidification (OA) scenario of elevated $\mathrm{PCO}_{2}(0.112$ vs. $0.039 \mathrm{kPa})$ at $10{ }^{\circ} \mathrm{C}$. Furthermore, following chronic exposure to warming and acidification, energy metabolism and escape performance of temperate $P$. maximus were more affected by warming than OA. In line with the OCLTT concept, the present findings revealed impaired escape performance such as decreased mean phasic force and increased recovery time after exhaustive exercise in the upper thermal pejus range. The observed changes could be linked to a progressive warming-induced mismatch between aerobic energy supply and demand, however, without a synergistic impact of exposure to ocean acidification.

Neither warm incubation nor OA exposure nor the combination of both affected the condition indices $(\mathrm{CI})$, which were similar to previous studies on other scallop species (Pazos et al. 1997; Shriver et al. 2002; Schalkhausser et al. 2013). This shows that the scallops used in the experiments were in good condition. Low mortality indicated further that the chosen OWA scenario (about $5{ }^{\circ} \mathrm{C}$ above the environmental summer mean temperature) was in the 

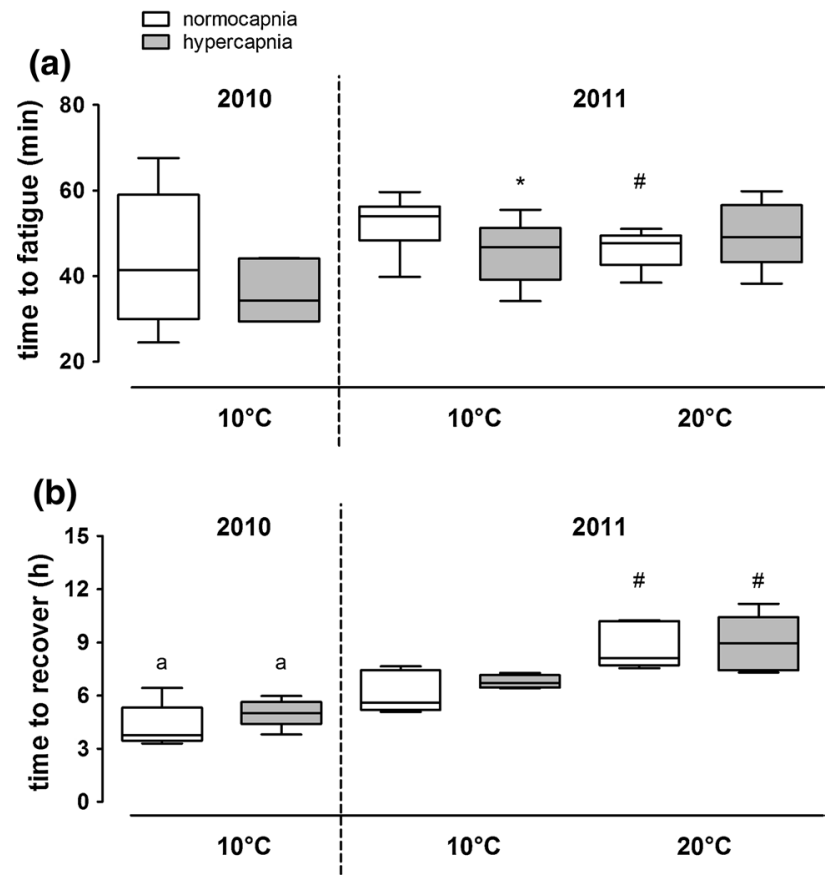

Fig. 2 Time to fatigue (a) and to recover from exhaustive exercise (b) of $P$. maximus from two different sampling years following longterm incubation under normocapnia (sea water $\mathrm{PCO}_{2} \sim 0.040 \mathrm{kPa}$ ) and hypercapnia (sea water $\mathrm{PCO}_{2} \sim 0.112 \mathrm{kPa}$ ) at two different temperatures $\left(10,20^{\circ} \mathrm{C}\right) .2010: N=5-8 ; 2011: N=6-10$ (normocapnia, $10^{\circ} \mathrm{C}$ ), $N=4-5$ (hypercapnia, $10^{\circ} \mathrm{C}$ ), $N=5-10$ (normocapnia, $20{ }^{\circ} \mathrm{C}$ ), $N=9$ (hypercapnia, $20^{\circ} \mathrm{C}$ ). Data are depicted in boxplots. ${ }^{a}$ Significant difference between sampling years at same $\mathrm{CO}_{2}$ level. *Significant differences between normocapnic and hypercapnic data at same temperature. "Significant differences between 10 and $20^{\circ} \mathrm{C}$ data at same $\mathrm{CO}_{2}$ level

range of thermal tolerance of temperate $P$. maximus and that experimental conditions did not exceed their critical temperatures. For comparison, in our previous study in boreal $P$. maximus from Norway, the observed high mortality of $90 \%$ among scallops sampled in winter $\left(3-5{ }^{\circ} \mathrm{C}\right)$ and exposed to $4{ }^{\circ} \mathrm{C}$ under hypercapnia (Schalkhausser et al. 2013) indicated that they were close to the lower limits of their thermal tolerance window.

The OA did not affect haemolymph oxygen partial pressures $\left(\mathrm{P}_{\mathrm{e}} \mathrm{O}_{2}\right)$ of $P$. maximus; values of $10-13 \mathrm{kPa}$ found under resting conditions at $10{ }^{\circ} \mathrm{C}$ are close to previous data on oysters (Jones et al. 1995; Lannig et al. 2008) and a spider crab (Frederich and Pörtner 2000). A temperature increase from 10 to $20{ }^{\circ} \mathrm{C}$, however, caused an almost twofold decline in $P_{\mathrm{e}} \mathrm{O}_{2}$ levels in both normocapnic and hypercapnic scallops. Such a decrease in haemolymph $\mathrm{PO}_{2}$ was also found in oysters subject to an acute temperature rise (Lannig et al. 2008) and matches observations in Northern boreal scallops incubated at $10{ }^{\circ} \mathrm{C}$ (Schalkhausser et al. 2013). The lowered $P_{\mathrm{e}} \mathrm{O}_{2}$ indicates that oxygen supply via ventilation and/or circulation could not keep up with the warming-induced increase in metabolism (see below), leading to the transition to the upper pejus range according to the OCLTT concept (Pörtner 2001, 2010).

Bivalves have only limited extracellular non-bicarbonate buffering capacities (Lindinger et al. 1984; Michaelidis et al. 2005; Melzner et al. 2009). Disturbances of $\mathrm{pH}_{\mathrm{e}}$ usually follow a non-bicarbonate buffer line similar to that

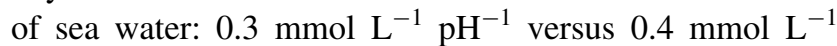
$\mathrm{pH}^{-1}\left(\beta_{\mathrm{NB}}\right.$ of Mytilus edulis, Booth et al. 1984). Accordingly, in OA-exposed temperate $P$. maximus, we found a reduction in $\mathrm{pH}_{\mathrm{e}}$ combined with elevated $P_{\mathrm{e}} \mathrm{CO}_{2}$, bicarbonate and $\mathrm{C}_{\mathrm{e}} \mathrm{CO}_{2}$ levels in the haemolymph, independent of incubation temperature, which corresponds to previous observations in Northern boreal P. maximus from Stavanger, Norway (Schalkhausser et al. 2013). In both cases, the elevation in extracellular bicarbonate levels was insufficient to fully compensate for the OA-induced extracellular acidosis. Interestingly, we noticed a possible difference in OA effects on haemolymph parameters between the populations, which was more pronounced after warming to either $20{ }^{\circ} \mathrm{C}$ (temperate) or $10{ }^{\circ} \mathrm{C}$ (boreal). Temperate $P$. maximus showed an OA-induced increase in $\left[\mathrm{HCO}_{3}{ }^{-}\right]_{\mathrm{e}}$ by $\sim 0.32 \mathrm{mM}$ $\left(20{ }^{\circ} \mathrm{C}\right)$ compared to the boreal population, where $\left[\mathrm{HCO}_{3}{ }^{-}\right]_{\mathrm{e}}$ increased by only $\sim 0.17 \mathrm{mM}\left(10{ }^{\circ} \mathrm{C}\right)$ at similar $\mathrm{PCO}_{2}$ s. This difference corresponds to the OA-induced drop in $\mathrm{pH}_{\mathrm{e}}$ which was less in temperate $(\sim 0.15 \mathrm{pH}$ units) than in boreal $P$. maximus ( $\sim 0.25 \mathrm{pH}$ units). This observation suggests that the capacity for acid-base regulation is somewhat higher in the temperate than in the boreal P. maximus population following OA exposure in the respective upper pejus range. In this context, it is worth noting that warm incubation did not affect $\mathrm{pH}_{\mathrm{e}}$ in the temperate population (Table 3) but significantly increased haemolymph $\mathrm{pH}$ from $7.41 \pm 0.23$ to $7.65 \pm 0.07$ and decreased $P_{e} \mathrm{CO}_{2}$ from $0.21 \pm 0.06$ to $0.13 \pm 0.02 \mathrm{kPa}$ in boreal normocapnic $P$. maximus (4 vs. $10{ }^{\circ} \mathrm{C}$, B. Schalkhausser, C. Bock, H.O. Pörtner, G. Lannig, unpublished data). Understanding the underlying mechanisms will require further studies.

Ocean acidification either by itself or when combined with warming (OWA) had no impact on aerobic metabolic rates of $P$. maximus measured at rest (RMR) and after exhaustive exercise (MMR). Warming from 10 to $20{ }^{\circ} \mathrm{C}$ caused a significant rise in RMR in both normocapnic and hypercapnic scallops. The $Q_{10}$ values of $\sim 2.3$ indicate an uncompensated temperature effect on energy demand regardless of $\mathrm{CO}_{2}$ exposure. This lack of thermal compensation has been described previously for P. magellanicus (Pilditch and Grant 1999; MacDonald and Thompson 1986; Shumway et al. 1988) and for other bivalves (Peck et al. 2002; Lannig et al. 2006; Morley et al. 2012).

Due to the warming-induced rise in RMR but not in MMR, FAS of $P$. maximus was lower at $20{ }^{\circ} \mathrm{C}$ than at 


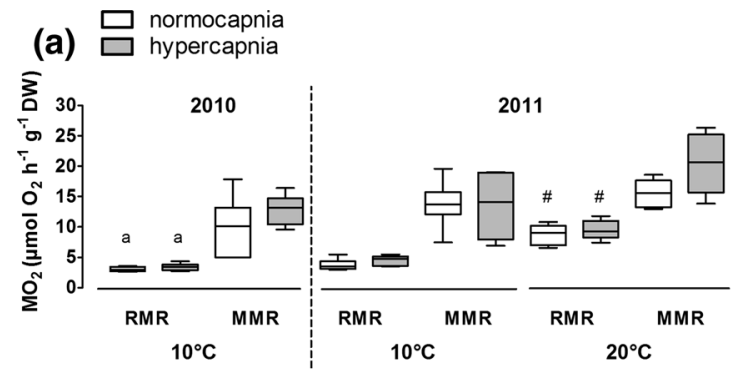

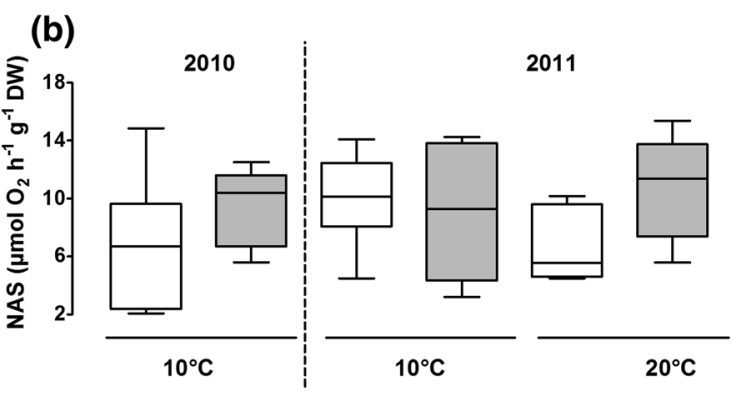

Fig. 3 Metabolic rates under resting (RMR) and fatigued (MMR) conditions (a), net aerobic scope (NAS, b) and factorial aerobic scope (FAS, c) of $P$. maximus from two different sampling years following long-term incubation under normocapnia (sea water $\mathrm{PCO}_{2} \sim 0.040 \mathrm{kPa}$ ) and hypercapnia (sea water $\mathrm{PCO}_{2} \sim 0.112 \mathrm{kPa}$ ) at two different temperatures $\left(10,20^{\circ} \mathrm{C}\right) .2010: N=7-8 ; 2011: N=7$

$10{ }^{\circ} \mathrm{C}$; however, any effect on NAS was minimal. Interestingly, additional OA exposure had no further impact. In our previous study, we had observed an OA-induced reduction in both factorial and NAS as well as in swimming performance of boreal $P$. maximus from Norway after warming from 4 to $10{ }^{\circ} \mathrm{C}$ (Schalkhausser et al. 2013). In both studies, scallops had similarly low haemolymph $\mathrm{PO}_{2}$ values $(6.2-6.5 \mathrm{kPa})$ and displayed a reduction in aerobic scope following warm exposure $\left(20{ }^{\circ} \mathrm{C}\right.$ for temperate and $10{ }^{\circ} \mathrm{C}$ for boreal $P$. maximus, respectively) which indicates that both populations were in their respective upper thermal pejus range. Compared to its Norwegian conspecific, temperate P. maximus, however, was less sensitive to OA, possibly due to the smaller decrease in its $\mathrm{pH}_{\mathrm{e}}$ following $\mathrm{OA}$ exposure and warming (see above). According to Pörtner (2008) (see also Wittmann and Pörtner 2013), OAinduced disturbances in $\mathrm{pH}_{\mathrm{e}}$, and thus ion exchange rates, influence cellular processes and functions. Thus, impaired performance capacities might become more prominent at larger OA-induced $\mathrm{pH}_{\mathrm{e}}$ alterations. To what extent annual $\mathrm{PCO}_{2}$ fluctuations in the natural habitats of the investigated populations might relate to the different $\mathrm{OA}$ sensitivities remains to be explored. Thermal sensitivity of escape performance in scallops may also depend on environmental history (Guderley et al. 2009). Warm incubation of winter (boreal $P$. maximus, previous study) versus warm incubation of late summer scallops (temperate $P$. maximus, present (c)

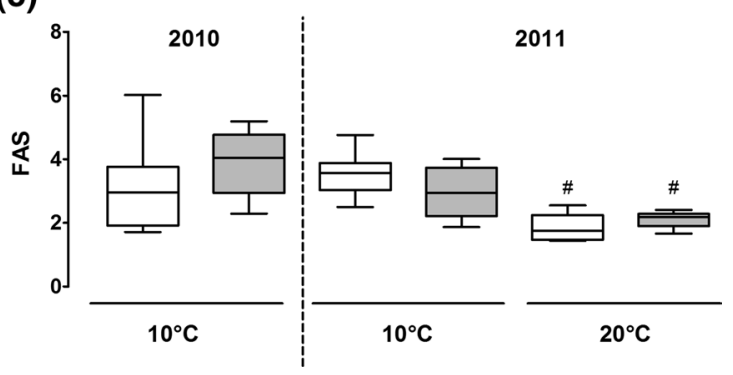

(normocapnia, $10{ }^{\circ} \mathrm{C}$ ), $N=5$ (hypercapnia, $10{ }^{\circ} \mathrm{C}$ ), $N=5$ (normocapnia, $20{ }^{\circ} \mathrm{C}$ ), $N=9$ (hypercapnia, $20^{\circ} \mathrm{C}$ ). Data are depicted in

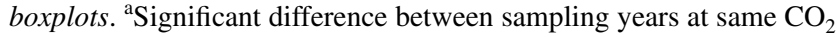
level. *Significant differences between normocapnic and hypercapnic data at same temperature. "Significant differences between 10 and $20{ }^{\circ} \mathrm{C}$ data at same $\mathrm{CO}_{2}$ level

study) might also explain the differences in OA sensitivity observed in the populations. However, since both populations were in their respective upper thermal pejus range, the key reason for the lower impairment in escape performance in temperate compared to boreal OA-exposed scallops is most likely the difference in OA-induced extracellular acidosis.

In the present study, temperature more than OA exposure had a large impact on escape performance of temperate $P$. maximus indicated by the significantly decreased mean phasic force at $20{ }^{\circ} \mathrm{C}$ compared to $10{ }^{\circ} \mathrm{C}$. Interestingly, this force reduction could not be linked to the lower MI in the warmth, because mean phasic force was similar between sampling years although the MI was significantly lower in 2010 than in 2011.

This temperature effect matches earlier findings by Guderley et al. (2009), who observed a negative warming effect $\left(6 / 12-18 / 19{ }^{\circ} \mathrm{C}\right)$ on phasic contraction in the scallop, P. magellanicus. However, total force (present study) and force of the tonic muscle (present study and Guderley et al. 2009) increased in the warmth, indicating an augmented use of the tonic muscle. In scallops, ATP generation for swimming is firstly and mainly fuelled by phosphorL-arginine (PLA) degradation followed by anaerobic glycolysis and octopine formation during escape response or recovery (Grieshaber 1978; de Zwaan et al. 1980; Bailey et al. 2003). Pérez et al. (2008a) suggested that the interplay 
between phasic and tonic contractions allows partial recuperation of the phasic muscle during periods when the tonic muscle is used. Guderley et al. (2009) suggested further that a temperature-induced decrease in phasic performance reflects a limitation in endurance performance (i.e. overall rate of phasic contractions) rather than in the initial clapping response, due to the interplay between phasic and tonic muscle performance. These assumptions match our observations as the number of claps was not influenced by warming despite lowered metabolic scope at $20{ }^{\circ} \mathrm{C}$ compared to $10{ }^{\circ} \mathrm{C}$. We observed a reduction in time to fatigue as well as a prolongation of the recovery period in warmcompared to control-exposed scallops under normocapnia. These findings suggest that scallops at their upper thermal limits in a warming ocean may suffer more from the same or a higher predation pressure with likely consequences at the ecosystem level. Furthermore, complete recovery from fatigue, while initially supported by anaerobic glycolysis, requires aerobic metabolism (Grieshaber 1978; Thompson et al. 1980; Bailey et al. 2003). Due to higher baseline costs at $20^{\circ} \mathrm{C}$ than at $10^{\circ} \mathrm{C}$, indicated by elevated RMR and lowered haemolymph $\mathrm{PO}_{2}$ values, the period needed to recover from exhaustive exercise was significantly extended in the warmth. Furthermore, we found the shortest recovery time in scallops from 2010, which also displayed the lowest RMR. This indicates a strong positive correlation between baseline costs and the ability to recover from exercise in line with the aerobic power budgeting concept (Guderley and Pörtner 2010).

In line with the OCLTT concept, the present findings revealed impaired performance in the upper thermal pejus range linked to a progressive warming-induced mismatch between aerobic energy supply and demand due to a warming-induced rise in maintenance costs. Performance thus does not exclusively depend on anaerobic metabolic capacity. In contrast to our initial working hypothesis and previous study (Schalkhausser et al. 2013), we observed no further impact following additional exposure to ocean acidification suggesting that the temperate scallop population is not highly affected by predicted OA scenarios with respect to swimming performance and escape behaviour from predators. The OA-induced acidification of the haemolymph was larger in boreal P. maximus (Norway, previous study) than in temperate P. maximus (France, present study) and might explain the lower sensitivity to OA in the temperate population when in the upper thermal pejus range. The impact of $\mathrm{pH}_{\mathrm{e}}$ variations on performance capacities merits further investigation to improve our understanding of the mechanisms defining sensitivity towards OWA.

Acknowledgments We would like to thank "Station Biologique de Roscoff", especially Yann Fontana (diver) and Pascal Morin (SOMLIT sea water database), for their support in scallops and environmental data supply. We thank S. Hardenberg and F. Véliz Moraleda for their help during scallop transportation. We also gratefully acknowledge the support of N. Klassen, I. Luedeke, C. Otten, A. Tillmann and $\mathrm{F}$. Wermter, who assisted in animal care and water analysis during the incubation experiments. We thank E. Schaum for statistical help and her and L. Fillinger for help in communication in French. We are grateful for the constructive comments on the manuscript of two anonymous reviewers. Scallop supply was funded by ASSEMBLE (Association of European Marine Biological Laboratories; EU FP7 research infrastructure initiative, Grant Agreement No. 227799). The study was funded by the Bundesministerium für Bildung und Forschung (BMBF)-funded project "Biological Impacts of Ocean Acidification" (BIOACID, FKZ 03F0608B) and is part of the "Polar regions and coasts in a changing Earth system" (PACES) research programme of the Alfred Wegener Institute.

Ethical standard We hereby declare that the experiments comply with the current laws of the country in which they were performed.

\section{References}

Aldridge DW, Payne BS, Miller AC (1995) Oxygen consumption, nitrogenous excretion, and filtration rates of Dreissena polymorpha at acclimation temperatures between 20 and $32^{\circ} \mathrm{C}$. Can J Fish Aquat Sci 52:1761-1767

Alejandrino A, Puslednik L, Serb JM (2011) Convergent and parallel evolution in life habit of the scallops (Bivalvia: Pectinidae). BMC Evol Biol 11:164. doi:10.1186/1471-2148-11-164

Bailey DM, Peck LS, Bock C, Pörtner HO (2003) High-energy phosphate metabolism during exercise and recovery in temperate and Antarctic scallops: an in vivo ${ }^{31} \mathrm{P}-\mathrm{NMR}$ study. Physiol Biochem Zool 76:622-633

Booth CE, McDonald DG, Walsh PJ (1984) Acid-base balance in the sea mussel, Mytilus edulis. I. Effects of hypoxia and air-exposure on hemolymph acid-base status. Mar Biol Lett 5:347-358

Chantler PD (2006) Scallop adductor muscles: structure and function. In: Shumway SE, Parsons GJ (eds) Scallops: biology, ecology and aquaculture, 1st edn. Elsevier, Amsterdam, pp 229-316

Clark TD, Sandblom E, Jutfelt F (2013) Aerobic scope measurements of fishes in an era of climate change: respirometry, relevance and recommendations. J Exp Biol 216:2771-2782

Cutts CJ, Metcalfe NB, Taylor AC (2002) Juvenile Atlantic salmon (Salmo salar) with relatively high standard metabolic rates have small metabolic scopes. Funct Ecol 16:73-78

de Zwaan A, Thompson RJ, Livingston DR (1980) Physiological and biochemical aspects of the valve snap and valve closure responses in the giant scallop Placopecten magellanicus II. Biochemistry. J Comp Physiol B 137:105-114

Findlay HS, Kendall MA, Spicer JI, Widdicombe S (2010) Relative influences of ocean acidification and temperature on intertidal barnacle post-larvae at the northern edge of their geographic distribution. Estuar Coast Shelf S 86:675-682

Frederich M, Pörtner HO (2000) Oxygen limitation of thermal tolerance defined by cardiac and ventilatory performance in the spider crab, Maja squinado (Decapoda). Am J Physiol 279:R1531-R1538

Fry FE (1947) Effects of the environment on animal activity. Univ Toronto Biol Ser 55. Pub Ont Fish Res Lab 68:1-62

Grieshaber M (1978) Breakdown and formation of high-energy phosphates and octopine in the adductor muscle of the scallop, Chlamys opercularis (L.), during escape swimming and recovery. $\mathrm{J}$ Comp Physiol B 126:269-276

Guderley H (2004) Locomotor performance and muscle metabolic capacities: impact of temperature and energetic status. Comp Biochem Physiol B 139:371-382 
Guderley H, Pörtner HO (2010) Metabolic power budgeting and adaptive strategies in zoology: examples from scallops and fish. Can J Zool 88:753-763

Guderley HE, Tremblay I (2013) Escape responses by jet propulsion in scallops. Can J Zool 91:420-430

Guderley H, Janssoone X, Nadeau M, Bourgeois M, Cortés HP (2008) Force recordings during escape responses by Placopecten magellanicus (Gmelin): seasonal changes in the impact of handling stress. J Exp Mar Biol Ecol 355:85-94

Guderley H, Labbé-Gigère S, Janssoone X, Bourgeois M, Pérez HM, Tremblay I (2009) Thermal sensitivity of escape performance by the scallop Placopecten magellanicus: impact of environmental history. J Exp Mar Biol Ecol 377:113-119

Hiebenthal C, Philipp EER, Eisenhauer A, Wahl M (2013) Effects of seawater $\mathrm{pCO}_{2}$ and temperature on shell growth, shell stability, condition and cellular stress of Western Baltic Sea Mytilus edulis (L.) and Arctica islandica (L.). Mar Biol 160:2073-2087

Ifremer (2011) Annual report 2011. http://www.ifremer.fr. Accessed 05 Dec 2012

IPCC (2014) Summary for Policymakers. In: Edenhofer O, PichsMadruga R, Sokona Y, Farahani E, Kadner S, Seyboth K, Adler A, Baum I, Brunner S, Eickemeier P, Kriemann B, Savolainen J, Schlömer S, von Stechow C, Zwickel T, Minx JC (eds) Climate change 2014, mitigation of climate change. Contribution of working group III to the Fifth Assessment Report of the Intergovernmental Panel on Climate Change. Cambridge University Press, Cambridge, United Kingdom and New York, NY, USA

Jones TO, Whyte JNC, Townsend LD, Ginther NG, Iwama GK (1995) Effects of domoic acid on haemolymph $\mathrm{pH}, \mathrm{PCO}_{2}$, and $\mathrm{PO}_{2}$, in the Pacific oyster, Crassostrea gigas and the California mussel, Mytilus californianus. Aquat Toxicol 31:43-55

Lafrance M, Guderley H, Cliche G (2002) Low temperature, but not air exposure, slows the recuperation of juvenile scallops, Placopecten magellanicus, from exhausting escape responses. J Shellfish Res 21:605-618

Lannig G, Flores JF, Sokolova IM (2006) Temperature-dependent stress response in oysters, Crassostrea virginica: pollution reduces temperature tolerance in oysters. Aquat Toxicol 79:278-287

Lannig G, Cherkasov AS, Pörtner HO, Bock C, Sokolova IM (2008) Cadmium-dependent oxygen limitation affects temperature tolerance in eastern oysters (Crassostrea virginica Gmelin). Am J Physiol 294:R1338-R1346

Lindinger MI, Lawren DJ, McDonald DG (1984) Acid-base balance in the sea mussel Mytilus edulis. Effects of environmental hypercapnia on intra and extracellular acid-base balance. Mar Biol Lett 5:371-381

MacDonald BA, Thompson RJ (1986) Influence of temperature and food availability on the ecological energetics of the giant scallop, Placopecten magellanicus. III. Physiological ecology, the gametogenic cycle and scope for growth. Mar Biol 93:37-48

Melzner F, Gutowska MA, Langenbruch M, Dupont S, Lucassen M, Thorndyke MC, Bleich M, Pörtner HO (2009) Physiological basis for high $\mathrm{CO}_{2}$ tolerance in marine ectothermic animals: preadaptation through lifestyle and ontogeny? Biogeosciences 6:1-19

Michaelidis B, Ouzounis C, Paleras A, Pörtner HO (2005) Effects of long-term moderate hypercapnia on acid-base balance and growth rate in marine mussels Mytilus galloprovincialis. Mar Ecol Prog Ser 293:109-118

Minchin D (2003) Introductions: some biological and ecological characteristics of scallops. Aquat Living Resour 16:521-532

Morley SA, Hirse T, Thorne MAS, Pörtner HO, Peck LS (2012) Physiological plasticity, long term resistance or acclimation to temperature, in the Antarctic bivalve, Laternula elliptica. Comp Biochem Physiol A 162:16-21
Pazos AJ, Roman G, Acosta CP, Abad M, Sanchez JL (1997) Seasonal changes in condition and biochemical composition of the scallop Pecten maximus L. from suspended culture in the Ria de Arousa (Galicia, N.W., Spain) in relation to environmental conditions. J Exp Mar Biol Ecol 211:169-193

Peck LS, Pörtner HO, Hardewig I (2002) Metabolic demand, oxygen supply and critical temperatures in the Antarctic bivalve Laternula elliptica. Physiol Biochem Zool 75:123-133

Pérez HM, Janssoone X, Guderley H (2008a) Tonic contractions allow metabolic recuperation of the adductor muscle during escape responses of giant scallop Placopecten magellanicus. J Exp Mar Biol Ecol 360:78-84

Pérez HM, Janssoone X, Nadeau M, Guderley H (2008b) Force production during escape responses by Placopecten magellanicus is a sensitive indicator of handling stress: comparison with adductor muscle adenylate energy charge and phosphoarginine levels. Aquaculture 282:142-146

Pilditch CA, Grant J (1999) Effect of temperature fluctuations and food supply on the growth and metabolism of juvenile sea scallops (Placopecten magellanicus). Mar Biol 134:235-248

Pörtner HO (2001) Climate change and temperature-dependent biogeography: oxygen limitation of thermal tolerance in animals. Naturwissenschaften 88:137-146

Pörtner HO (2002) Environmental and functional limits to muscular exercise and body size in marine invertebrate athletes. Comp Biochem Physiol A 133:303-321

Pörtner HO (2008) Ecosystem effects of ocean acidification in times of ocean warming: a physiologist's view. Mar Ecol Prog Ser 373:203-217. doi:10.3354/meps07768

Pörtner HO (2010) Oxygen- and capacity-limitation of thermal tolerance: a matrix for integrating climate-related stressor effects in marine ecosystems. J Exp Biol 213:881-893. doi:10.1242/ jeb. 037523

Pörtner HO, Farrell AP (2008) Physiology and climate change. Science 322:690-692

Pörtner HO, Bock C, Knust R, Lannig G, Lucassen M, Mark FC, Sartoris FJ (2008) Cod and climate in a latitudinal cline: physiological analyses of climate effects in marine fishes. Clim Res 37:253-270

Precht H, Christopherson J, Hensel H, Larcher W (1973) The timetemperature relation of heat killing. In: Precht $\mathrm{H}$, Christopherson J, Hensel H, Larcher W (eds) Temperature and life, 1st edn. Springer, Berlin, pp 17-20

Rodolfo-Metalpa R, Houlbrèque F, Tambutté É, Boisson F, Baggini C, Patti FP, Jeffree R, Fine M, Foggo A, Gattuso J-P, Hall-Spencer JM (2011) Coral and mollusc resistance to ocean acidification adversely affected by warming. Nat Clim Change 1:308-312. doi:10.1038/NCLIMATE1200

Rosa R, Seibel BA (2008) Synergistic effects of climate related variables suggest future physiological impairment in a top oceanic predator. Proc Natl Acad Sci USA 105:20776-20780

Schalkhausser B, Bock C, Stemmer K, Brey T, Pörtner HO, Lannig G (2013) Impact of ocean acidification on escape performance of the king scallop, Pecten maximus, from Norway. Mar Biol 160:1995-2006. doi:10.1007/s00227-012-2057-8

Shriver AC, Carmichael RH, Valiela I (2002) Growth, condition, reproductive potential, and mortality of bay scallops, Argopecten irradians, in response to eutrophic-driven changes in food resources. J Exp Mar Biol Ecol 279:21-40

Shumway SE, Barter J, Stahlnecker J (1988) Seasonal changes in oxygen consumption of the giant scallop, Placopecten magellanicus (Gmelin). J Shellfish Res 7:77-82

Sokolova IM, Frederich M, Bagwe R, Lannig G, Sukhotin AA (2012) Energy homeostasis as an integrative tool for assessing limits of environmental stress tolerance in aquatic invertebrates. Mar Environ Res 79:1-15 
Somero GN (2011) Comparative physiology: a "crystal ball" for predicting consequences of global change. Am J Physiol Regul Integr Comp Physiol 301:R1-R14. doi:10.1152/ajpregu.00719.2010

Thompson RJ, Livingstone DR, de Zwaan A (1980) Physiological and biochemical aspects of the valve snap and valve closure responses in the giant scallop Placopecten magellanicus I Physiology. J Comp Physiol 137:97-104

Tremblay I, Guderley HE, Himmelmann JH (2012) Swimming away or clamming up: the use of phasic and tonic adductor muscles during escape responses varies with shell morphology in scallops. J Exp Biol 215:4131-4143

Weiss RF (1974) Carbon dioxide in water and seawater: the solubility of a non-ideal gas. Mar Chem 2:203-215

Wittmann A, Pörtner HO (2013) Sensitivities of extant animal taxa to ocean acidification. Nat Clim Change 3:995-1001. doi:10.1038/ nclimate 1982 